\title{
First report of Colletotrichum gloeosporioides causing anthracnose on Blepharocalyx salicifolius in Argentina
}

\author{
Silvina Larran • José Vera Bahima • Gustavo Dal Bello
}

Received: 17 December 2010/Accepted: 10 March 2011/Published online: 4 May 2011

(C) Australasian Plant Pathology Society Inc. 2011

\begin{abstract}
Anthracnose symptoms were observed on Blepharocalyx salicifolius from Entre Ríos and Buenos Aires provinces, Eastern Argentina. Colletotrichum gloeosporioides sensu lato (teleomorph Glomerella cingulata) was identified as the causal agent based on disease symptoms, the morphological characteristics of the isolated fungus and pathogenicity tests. To our knowledge, this is the first report of $C$. gloeosporioides causing leaf spot on Blepharocalyx salicifolius.
\end{abstract}

\section{Keywords Glomerella cingulata $\cdot$ Colletotrichum gloeosporioides $\cdot$ Anacahuita $\cdot$ Blepharocalyx salicifolius}

Blepharocalyx salicifolius (Hum., Bompl. \& Kunth) Berg in the Myrtaceae, locally known as Anacahuita, is a common perennial native tree from South America (Southern Brasil, Uruguay and Northeast Argentina). Anacahuita is a valuable ornamental and medicinal plant, which grows in coastal and mountain forests and is also found in the riparian zone of La Plata and in the

S. Larran $(\bowtie) \cdot J$. V. Bahima $\cdot$ G. Dal Bello Centro de Investigaciones de Fitopatología,

Facultad de Ciencias Agrarias y Forestales, UNLP, 60 y 119, La Plata 1900, Buenos Aires, Argentina

e-mail: silvinalar@gmail.com

J. V. Bahima

Consejo Nacional de Investigaciones

Científicas y Técnicas (Conicet),

La Plata 1900, Buenos Aires, Argentina

G. Dal Bello

Comisión de Investigaciones

Científicas de la Provincia de Buenos Aires (CIC),

La Plata 1900, Buenos Aires, Argentina
Delta, Buenos Aires province (Cabrera and Zardini 1978; Parodi 1979).

During spring 2010, severe foliar anthracnose was observed in production nurseries at the El Palmar area in Entre Ríos. Leaves with symptoms were also collected from a mature tree in La Plata, Buenos Aires province. Typical symptoms appeared as circular and irregular light brown lesions of 2-4 mm in diam., isolated and surrounded by a red halo (Fig. 1). In older lesions, black sub-epidermal acervuli with dark setae were observed (Fig. 2).

Samples from tissue adjacent to spots were collected and their surfaces were sterilised through washing for $30 \mathrm{~s}$ in $70 \%$ ethanol, followed by $1 \%$ sodium hypochlorite for $30 \mathrm{~s}$, and sterile distilled water. These samples were plated in Petri dishes containing potato dextrose agar (PDA) and incubated at $25^{\circ} \mathrm{C}$ with a $12 \mathrm{~h}$ alternating light and dark cycle. After 10 days emerged fungal colonies were sub-cultured on PDA and pure cultures obtained using the single spore method.

Isolation from symptomatic tissues of plants from two origins consistently yielded greyish white abundant aerial mycelium, with acervuli containing slimy, salmon-pink masses of spores and dark setae. Conidia were straight, one-celled, hyaline, oblong, or cylindrical with rounded ends $(10-14 \times 4.0-4.5 \mu \mathrm{m})$. Scarce dark brown perithecia developed in 20-days-old cultures but not were observed in leaves tissues. Asci were not conspicuous and contained slightly curved ascospores $(12-17 \times 4-5 \mu \mathrm{m})$. The fungus was identified as Glomerella cingulata (Stoneman) Spauld. \& Schrenk (anamorph: Colletotrichum gloeosporioides sensu lato (Penz.) Penz. \& Sacc.) based in morphological and cultural characteristics (Sutton 1980). Colletotrichum gloeosporioides sensu lato is a species complex with broad genetic and biological diversity grouped together by similar conidial morphology and ITS sequences (Hyde et al. 2009; Damm et al. 2010). Pathogenicity of the fungus isolates was 
Fig. 1 Symptoms of anthracnose caused by $C$. gloeosporioides on B. salicifolius. Left, necrotics spots on leaves and right, acervuli

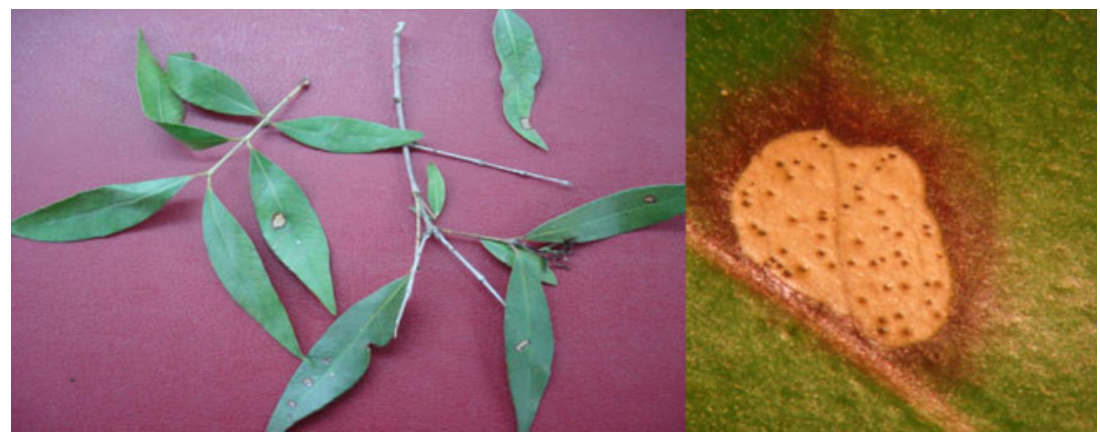

confirmed by inoculating non-wounded leaves of healthy branch plants with a conidial suspension $\left(1 \times 10^{6}\right.$ spores $\left./ \mathrm{mL}\right)$ until run-off. Leaves of plants sprayed with distilled water were used as controls. Branches of plants were covered with plastic bags for $48 \mathrm{~h}$. After 15 days, lesions similar to the original symptoms were observed on inoculated plants and C. gloeosporioides was successfully re-isolated from the lesions, fulfilling Koch's Postulates. Control plants sprayed with distilled water remained symptomless. A culture of the pathogen has been deposited in the Culture Collection of the Centro de Investigaciones de Fitopatología, Facultad de Ciencias Agrarias y Forestales, University of La Plata, as CG1.

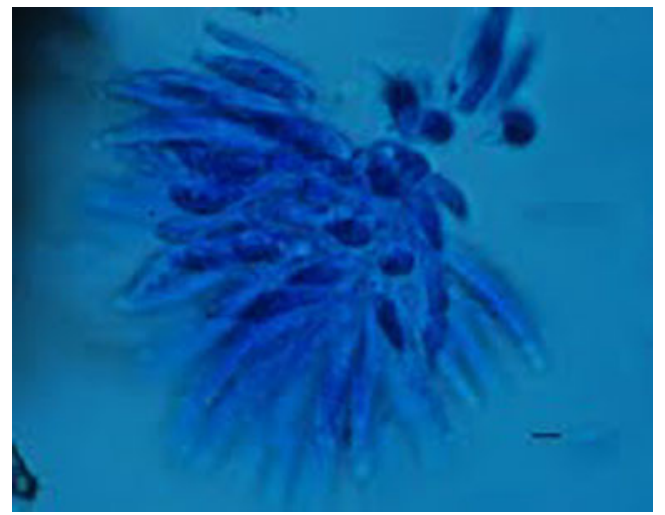

Fig. 2 Glomerella cingulata asci with ascospores. Bar $=20 \mu \mathrm{m}$
The fungus was cited as endophyte colonizing healthy leaf and bark of B. salicifolius in Uruguay (Bettucci et al. 2004). To our knowledge, this is the first report of Glomerella cingulata causing anthracnose on Blepharocalyx salicifolius.

Acknolowgements The authors thank Dr Néstor Bayón for the identification of the Blepharocalyx salicifolius.

\section{References}

Bettucci L, Simeto S, Alonso R, Lupo S (2004) Endophytic fungi of twigs and leaves of three native species of Myrtaceae in Uruguay. Sydowia 56:8-23

Damm U, Baroncelli R, Cai L, Kubo Y, O'Connell R, Weir B, Yoshino K, Cannon PF (2010) Colletotrichum: species, ecology and interactions. IMA Fungus 1:161-165

Cabrera AL, Zardini EM (1978) Manual de la Flora de los alrededores de Buenos Aires. ACME SACI, Buenos Aires

Hyde KD, Cai L, Cannon PF, Crouch JA, Crous PW, Damm U, Goodwin PH, Chen H, Johnston PR, Jones EBG, Liu ZY, McKenzie EHC, Moriwaki J, Noireung P, Pennycook SR, Pfenning LH, Prihastuti H, Sato T, Shivas RG, Tan YP, Taylor PWJ, Weir BS, Yang YL, Zhang JZ (2009) Colletotrichumnames in current use. Fungal Diversity 39:147-182

Parodi L (1979) Enciclopedia Argentina de Agricultura y Jardinería. ACME SACI, Buenos Aires. $3^{\circ}$ edición. Tomo I, Vol. II, pp. 657-1181

Sutton BC (1980) The Coelomycetes. Fungi Imperfecti with Pycnidia, Acervuli and Stromata. Commonwealth Mycological Institute, Kew, Surrey, Eng 